\title{
Sustainable Artisanal Fisheries Practices in Nigeria
}

\author{
SOGBESAN Olukayode Amos* and KWAJI Barka Peter \\ Department of Fisheries, Modibbo Adama University of Technology, Nigeria
}

Submission: June 30, 2017; Published: January 23, 2018

*Corresponding author: Sogbesan Olukayode, Department of Fisheries, Modibbo Adama University of Technology, Yola, Nigeria, Email: sokayfish@googlemail.com

\begin{abstract}
The paper attempts to examine the current trends of artisanal fisheries practices in inland waters of Nigeria. The paper discussed the potentials of inland fisheries resources, its advantages and the pressure on inland fisheries resources of Nigeria. Despites efforts by relevant agencies, bodies and institutions through regulations, control and monitoring, Unsustainable fisheries practices such as overfishing, use of destructive and damaging fishing methods as well as illegal, unregulated and unreported fisheries practices are still common practices among artisanal fishers in Nigeria. There is low adherence and compliance to fisheries regulations and sustainable fisheries practices among the artisanal fishers. These unsustainable fisheries practices are threatening the sustainability and benefits of the inland fisheries resources.

The paper also highlights the current challenges facing and militating against the sustainable development of artisanal fisheries in Nigeria, fisheries sustainability objectives and ecosystem effects of fishing. There is need for swift adoption and implementation of measures that will ensure sustainable exploitation, development and management of the inland fisheries resources of Nigeria. The paper recommends the need for enlightenment campaign on sustainable fisheries practices, regular programmers of overfished and depleted water bodies and integrates artisanal fishers as key stakeholders in fisheries policy formulation, management. Diversifying or providing an alternative source of income for the artisanal fishers would reduce the pressure on the resources by engaging in non-fishing activities. The need to strictly implement the newly enacted Inland fisheries Act, 2014 cannot be overemphasized.
\end{abstract}

Keywords: Artisanal fishers; Sustainability; Inland fisheries; Management

Abbreviations: MSY: Maximum Sustainable Yield; MEY: Maximum Economic Yield

\section{Introduction}

Nigeria, one of the most populated countries in West Africa has a land area of 923, 768km2 out of which 14 million hectares comprises inland waters Neiland et al. [1]. Nigeria has one of the highest fish yields per area within West Africa but consumption per person is one of the lowest due to the increase in the population density. About $80 \%$ of Nigeria's fish production comes from the artisanal fishery sector Neiland et al. [1]. Globally, inland artisanal fisheries have provided an important source of food for sustaining human well-being over the years Bene \& Heck [2]. Fish plays an important role in improving and sustaining food security and nutritional status for many isolated communities in rural areas Bene \& Heck [2]; Nwabeze \& Erie [3]. Fish and fishery products are a vital and affordable source of food and high-quality protein in 2008 fish as food reached an all-time high of nearly $17 \mathrm{~kg}$ per person, supplying over 3 billion people with at least $15 \%$ of their average animal protein intake FAO [4].

In Nigeria, artisanal inland fisheries do not only serve as an important alternative source of animal protein but also crucial to the economy, contributing about $5 \%$ of the gross domestic products of the country FDF [5]. The inland artisanal fisheries accounted for over $85 \%$ of domestic fish production between 1991 and 2003 with a total fish production of 615, 507metric tons in 2007 Nwabeze \& Erie [3]. Artisanal fisheries earn foreign exchange for the country, employment-creation, incomegeneration, while it is also a source of raw materials for the food and animal feeds industries [6]. Overall, in 2008, world exports of fish and fishery products reached a record US $\$ 102$ billion [7]. In Nigeria, the total export earnings from fish was USD 50 million while the import value was USD 375.03 million in 2001 [6].

Globally, in 2008, almost 45 million people were directly engaged in the fisheries sector [4]. Add to these the important secondary sectors such as handling and processing, and women represent half of those involved. The Federal Department of Fisheries (2009) reported that in the agricultural sector of the Nigerian economy which employs about $70 \%$ of the active labor force, fish occupies a unique position in that it is the cheapest source of animal protein consumed by average Nigerians, accounting for up to $50 \%$ of their total animal protein intake. There are a number of growing concerns about problems with 
the management of fisheries resources and fishing methods which are placing excessive strain on the water ecosystems, including rivers, which are major fishery resources.

Some of the concerns are: The increased capacity to exploit fish stocks due to increased demand and effort (time at river, number of boats) and improvement in fishing technology; Significant decline in fish stocks seen globally; The destruction or alteration of spawning and nursery grounds through fishing practices or coastal development. The growing population density around the globe is putting so much pressure on inland fisheries resources and had tended to increase over the whole continents over the last 20 years. As fishing effort increases, fishing impacts also increases leading to a decline in fish production in the subsequent fishery exploitation.

Unfortunately, the history of management of inland fisheries worldwide shows generally low success in containing the growing pressure on the natural fish stocks. It has been estimated that most of the world's major inland fisheries are now at their maximum level of exploitation. Despites the current contributions of inland fisheries and its potentials in Nigeria, its sustainability is threatened due to overexploitation of the natural stock (which is getting to its limit) and the use of unsustainable and destructive fisheries practices by the [8]. Sustainable fisheries management is important because millions of people's livelihoods depends on it. Since artisanal fisheries provides crucial role in the socio-economic and political wellbeing of many Nigerians, there is need to ensure complete protection, development, management and sustenance of both its aquatic environment and its vast inland fisheries resources to avoid stock depletion and collapse, and extinction of species.

\section{Potentials of Inland Fisheries Resources of Nigeria}

Nigeria lies between longitude $2^{\circ} 49^{\prime} \mathrm{E}$ and $4^{\circ} 16^{\prime} \mathrm{N}$ and $13^{\circ}$ $52^{\prime}$ North of the Equator [9]. The south (below $8^{\circ}$ ) has an annual rainfall ranging between 1,500 and $4,000 \mathrm{~mm}$ [9]. Nigeria is blessed with a vast expanse of inland resources (freshwater and brackish) which are contained within 320 nautical miles (667km) [9] (Figure 1).

\section{Niger North (Sokoto-Rima River)}

II. Niger Central (Kaduna River)
III. Upper Benue River (Gongola River)

IV. Lower Benue River (Benue River)

V. Niger South (Anambra River Basin)

VI. Western Littoral (Ogun River Basin, Osun River Basin and Osse River Basin)

VII. Eastern Lottoral (Cross River Basin)

VIII. Lake Chad (Hadejia River Basin) [10].

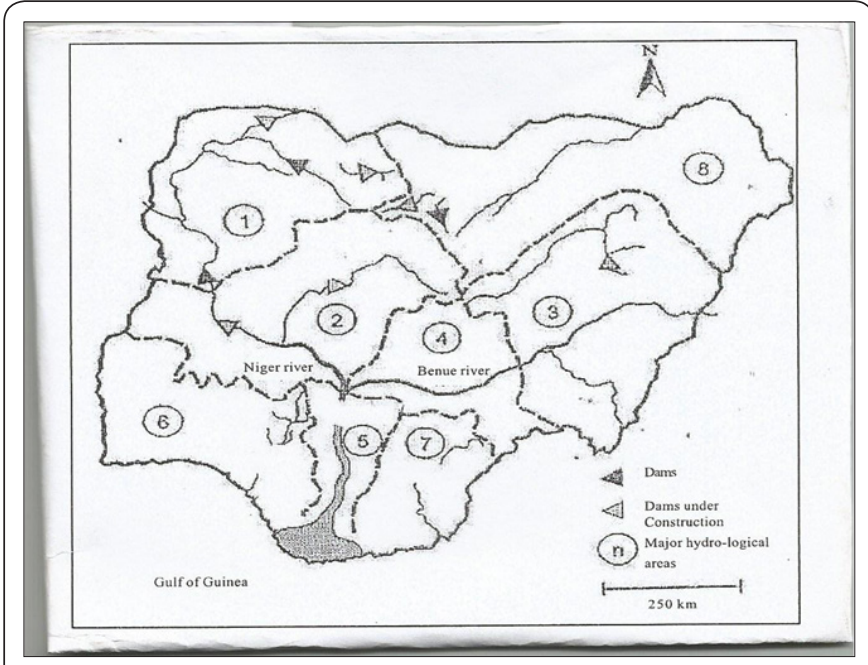

Figure1: Map of Nigeria showing major rivers and hydrological basins.

\section{Source}

The major rivers estimated at about 10, 812, 400ha (Table 1), make up about $11.5 \%$ of the total surface area of Nigeria which is estimated to be approximately $94,185,000$ ha [9]. Thirteen Lakes and Reservoirs with a surface area of between 4, 000 and 550,000 ha have a total surface area of 853,600 ha (Table 1 ) and represent about $1 \%$ of the total area in Nigeria [9]. Despites the overwhelming potentials of abundant fisheries resources, Nigeria still remain a large importer of fish [9]. Reasons for this has been attributed to the non-adherance to fishing laws and regulations, the subsistence nature of the fishers, the remoteness of fishing communities and the difficulty in accessing and use of outdated fishing gears and craft [11] including low adoption of improved fisheries technology and poor management practices adopted by fishers [3].

Table 1: Major inland water bodies of Nigeria.

\begin{tabular}{|c|c|c|}
\hline \multirow{2}{*}{ S/No. } & Type of Water Body & Approximate Surface Area (Ha ) \\
\cline { 2 - 3 } & Major Rivers & $1,401,000$ \\
\hline 1 & Anambra River & 129,000 \\
\hline 2 & Benue River & $3,900,000$ \\
\hline 3 & Cross River & 910,000 \\
\hline 4 & Imo River & \\
\hline
\end{tabular}


Oceanography \& Fisheries Open access Journal

\begin{tabular}{|c|c|c|}
\hline 5 & Kwa Iboe River & 160,200 \\
\hline 6 & Niger River & $2,237,000$ \\
\hline 7 & Ogun River & $1,565,400$ \\
\hline 8 & Oshun River & $10,812,400$ \\
\hline Sub- total & & Approximate surface area (Ha) \\
\hline & Major Lakes and Reservoirs & 550,000 \\
\hline 1 & Lake Chad (natural) & 127,000 \\
\hline 2 & Kainji Lake (man-made) & 35,000 \\
\hline 4 & Lake Jebba (man-made) & 31,200 \\
\hline 5 & Shiroro Lake (man-made) & 17,000 \\
\hline 6 & Goronyo Lake (man-made) & 10,100 \\
\hline 7 & Tiga Lake (man-made) & 29,000 \\
\hline 8 & Chalawa Gorge (man-made) & 11,500 \\
\hline 10 & Dadin Kowa Dam (man-made) & 8,000 \\
\hline 11 & Kiri Dam (man-made) & 5,000 \\
\hline 12 & Bakolori (man-made) & 4,000 \\
\hline Sub-total & Lower Anambra (man-made) & $11,666,000$ \\
\hline Grand total & Zobe (man-made) & $94,185,000 \mathrm{Ha}$. \\
\hline
\end{tabular}

Several attempts were made to boost the productivity of artisanal fishers through institutional reforms. The need to reverse the declining trends in capture fisheries resources compelled Government to formulate sustainable management strategies, which incorporates a combination of management measures, mainly technical and input controls and to some extent, output controls and economic incentives. These management measures are backed up by enactment of laws at the federal level and edicts at the state level [3]. The use of informal institutions in fisheries management has been reported in many inland waters of Nigeria [3] reported the relevance of traditional institution (Sarkin ruwa) in management of fisheries of Lake Jebba, Nigeria.

Despites these efforts, the fisheries sector have not been able to bridge the gap between fish demand and supply [12]. This has been partly blamed on the fisher's lack of adoption of sustainable fishing practices and sometimes lack of knowledge of sustainable fisheries practices [3]. Considering these and the dynamic nature of the ecosystems and its relation to human existence, an adequate review of past research work done becomes imperatives.

\section{Artisanal Fishing Pressure and its Impacts}

Artisanal fishing pressure is an indicator of how the harvesting of free-ranging fish from inland waters and high seas by small-scale fisheries can impact the success of future catches of wild fish harvests. These include catch and by-catch (both high and low) of fish, other seafood and marine wildlife [2]. Due to their size and practices, artisanal fisheries are potentially more sustainable than large-scale fisheries [11]. However, they also inflict pressure on the environment through overfishing and the use of destructive or unregulated fishing methods, which can result in high levels of by-catch, i.e. the catch of unintended species or undersized/under-aged specimens of a target species. The impacts of artisanal fishing pressure include the following:

\section{Ecological impacts}

Unsustainable fishing pressure alters the ecosystem structure and can have a significant impact upon biodiversity, productivity and overall food web dynamics. Destructive fishing practices result in by-catch, which is the catch of unintended species or undersized/under-aged specimens of the target species. By-catch of non-target species can harm the ecological structure of an ecosystem, affecting existing populations as well as potential future catch.

\section{Human health impacts}

Without the opportunity to catch their own food, millions of people could not meet their daily needs for protein. Fish provide more than 3 billion people, particularly in low-income, food deficient countries, with 15 percent of their average per capita intake of animal protein $[4,13]$.

\section{Economic impacts}

Artisanal fishing includes $90 \%$ of all fishing jobs worldwide, approximately $45 \%$ of the world's fisheries, and nearly a quarter of the world catch [11]. Of an estimated 170 million people in Nigeria, about 1\% engages in fisheries and over 24 million Nigerians depend on fisheries for their livelihood [14]. Comparatively, artisanal and commercial fisheries catch the same amount of fish for human consumption (30 million tons), 
yet artisanal fisheries employ 25 times the number of fishers (over 12 million people) and use an eighth of the amount of fuel used by industrial fisheries annually [13].

$70 \%$ of the world's total fish catch comes from developing countries, and over half of this comes from small-scale fisheries [13]. Net losses to the global economy from unsustainable exploitation of living marine resources are calculated to substantially exceed $\$ 50$ billion per year- equivalent to more than half the value of the global seafood trade [15]. Small-scale fisheries are susceptible to risks posed by natural disasters and fuel and fish price fluctuations [2].

\section{Unsustainable Fisheries Pratices}

Globally, so much fish is being taken out of waters and at such a fast rate, that the global fish populations cannot replenish itself naturally and therefore fish stocks are declining. The reasons for this huge fall are due to a number of reasons including unsustainable fisheries practices [16]. Unsustainable fishing practices are ways of catching wild fish that are not considered sustainable in the long term [17]. This could be because they threaten the fish stock itself by overfishing, or because they threaten the environment the fish need to thrive. Dynamite fishing, electro-fishing, use of gears with small mesh sizes, and fishing with poisons are examples of unsustainable fisheries practices used in developing countries including Nigeria [18].

In Nigeria, most inland waters are exploited by artisanal fisher folks [19] and Even with the problem of over fishing, they still employ various unorthodox means to continue exploiting the declining and degraded stocks [18]. The implication of over fishing resulting from exploiting the available fish resources intensively and frequently suggests the need to address sustainable exploitation of the fisheries resources. [17] and [19] describes the following as they are common unsustainable fisheries practices in developing countries including Nigeria.

\section{Overfishing}

Overfishing occurs when more fish are caught than the populations can replace through natural reproduction [19]. Gathering as many fish as possible may seem like a profitable practice, but overfishing has serious consequences. The results not only affect the balance of life in the water bodies, but also the social and economic well-being of the coastal communities who depend on fish for their way of life [17]. Overfishing covers three interconnected phenomena: biological overfishing, economic overfishing and ecosystem overfishing. Biological overfishing is a situation in which the fishing pressure exerted on the species is higher than the pressure required for harvesting the maximum sustainable yield (MSY), or would, if continued in the medium term, impair the population productivity.

Economic overfishing occurs when a fishery is generating a rent lower than the maximum rent obtainable (e.g. below maximum economic yield [MEY]), primarily because an excessive level of fishing effort was applied. Ecosystem overfishing is a situation in which the long-term historical species balance (i.e. species composition, dominance, and their natural oscillations) have been significantly modified by [17]. The key drivers of overfishing stem from open access to fish resources [17]. The phenomenon is fuelled by human quest for food and livelihood and the related economic and social forces. It is accelerated by demography (and related food demands), short-term economic profits and inadequate governance. Major factors that constrain the fight against overfishing include [17]. The lack of alternative livelihoods, particularly in rural areas; Inadequate governance, particularly lack of institutional cooperation and, coordination, both between fisheries and environmental agencies and across industry sectors; The insufficient capacity in management institutions, and particularly for monitoring, control and surveillance; Unfair Fisheries Partnership Agreements that allow foreign fleets to overfish in the waters of developing countries etc. [16].

Enaikele \& Olutayo [19] reported that the use of small mesh size nets posed a major problem of overfishing and depletion of inland fisheries stocks in Lagos State. They also confirmed that no one has ever been legally prosecuted in the fishing communities in the State. [19] also revealed that the open access to most inland waters in Lagos State has increased the fishing pressure that contributed to overfishing and depletion of the fisheries stocks otherwise known as the "the tragedy of the commons". This is so because the small mesh size nets most of the fishers uses have a great toll on the juvenile fish species [18]. The use of small mesh size nets is rampant at night [19].

The findings by Enaikele \& Olutayo [19] are considerably relevant for sociological interest because of the problem of the "tragedy of the commons" resulting from fisher's environmental interactions. Etim [20] attributed the problem of overexploitation to inventions and increased sophistication of fishing gears in recent times; which is in practice in Lake Kainji as reported by Alamu et al. [21] \& Eyo \& Ahmed [22]. Eyo \& Ahmed [22] reported a collapse of the fisheries resources of Lake Kainji due to overfishing and environmental pressures. He reported a reduction in the mean sizes (mean length and weight) in fish species and change in species composition due to recruitment and ecosystem overfishing.

He also reported a massive poaching of juvenile fishes in the Lake by foreign fishermen who utilize gill nets and beach seine nets with less than 3 inches as stipulated in the then inland waters decree of 1992. According to the author, the reckless fishermen have reduced the population of fish in the Lake from about 35, 000 metric tons to about less that 10, 000 metric tons. In Lake Chad Basin, overfishing was observed and reported by Stauch cited in Eyo and Ahmed [22] which the fishers resulted to using smaller mesh size nets which cropped the juveniles. A reduction from 220, 000 tons in 1974 to 31, 334 tons in 1985 was reported in Lake Chad Sagua, 1990; cited in Njoku \& Ejiogu [23]. Competitive fishing in the Lake promotes the capture of 
undersized fish. Mesh size regulation exist theoretically but enforcement is almost impossible [23].

Recent observations shows that there are few large fish and most are rarely more than $2 \mathrm{~kg}$ net weight at the various landing sites [23]. At the Lake, Overfishing is based on the use of nonselective nylon gill nets, seines, etc [23]. The rapid population rise around the Lake (7.4 million for all the riparian countries) [23] and the demand of fish all the countries makes fishers easily sell all their catch irrespective of size or species, all contributes to overfishing in the Lake. Other causes of overfishing in the Lake includes a deterioration of the socio-economic environment, absence of common fishery policy for the riparian nations, as well as post-harvest losses which encourages more fishing to offset such losses Ejiogu [23], Njoku et al. [24].

Keke et al. Njoku \& Ejiogu [23] and Anene et al. reported the use of beach seine nets, explosives (locally made grenades and dynamites), poisons and undersize mesh size gill nets as well as drag net in Lake Oguta. Anene and Njoku et al. [24] reported that the free and open access, and technological innovations (Motorized boats, mechanized outboard engines and sophisticated fishing gears like the purse seine nets, gill net-fleets etc.) introduced in Lake Oguta in recent times, have caused the fisheries resources of the Lake to be biologically and economically overfished.

\section{Destructive Fishing Practices}

Destructive fishing practices refers to the use of fishing gears in ways or in places such that one or more key components of an ecosystem are obliterated, devastated or ceases to be able to provide essential ecosystem functions [17]. Few, if any, fisheries are consistently "destructive" and only a very small number of fishing gears or fishing methods are recognized as inherently "destructive" wherever and however they are used, the primary examples being explosives and synthetic toxins [3]. Ita \& Balogun [25] reported that poisons and explosives are often used in shallow inlets (where spawning occurs) of Rivers and Reservoirs in Nigeria. Njoku \& Ejiogu [23] reported the use of poisons and beach seine nets at night in Lake Oguta by Artisanal Fishers.

The authors stressed that the application of such methods in such areas inevitably lead to mass mortality of juvenile fish that are most dominant age group in these vegetated inshore areas. Apart from the mass destruction of juveniles, the authors also reported that most of the fish killed are often recovered on either the second of third day after the application of the poison; which is not fit for consumption. Oruounye [26] reported that fishers do come at night to use chemicals such as Gamalin 20 to catch fish in Mayo Renewo Community in Ardo Kola Local Government of Taraba State, Nigeria.

The use of such chemical allows them to catch as much fish as they can within the shortest time but has negative effects on the ecosystem and the organisms that live there. Nwabeze \& Erie [3] reported the use of damaging fishing methods by fishers in Lake Jebba, which include beach seine nets and gamalin 20. When asked on why the fishers chose to use destructive fishing methods, Nwabeze \& Erie [3] reported that most of them said "fish species vary greatly in terms of habits and habitants, and as they change according to season, we equally have to change our gear and method of fishing so that we and our families can survive". Other unsustainable fishing practices adopted by the fishers as reported by Nwabeze \& Erie [3] in Lake Jebba Basin include gill nets with undersize mesh sizes, landing nets and fish fence traps. The researchers concluded that a large proportion of fishers in Lake Jebba Basin do not use fishing practices that will enhance the sustainability of the fisheries resources. Eyo \& Ahmed [22] reported that artisanal fishers still make use of explosives and poisons from time to time in Nigeria's inland waters to kill, daze or shock fish in order to catch them. Chemicals such as Gamalin 20, Aldrex 40, Didimacs 25, Atranex and Faenthion are commonly use by the artisanal fishers to catch fish in many inland waters of Nigeria Eyo \& Ahmed [22]. These chemicals are usually in liquid forms and are poured on the surface of water to narcotize and kill fish. The author also identified the use of Ichthyotoxic plants in Kainji Lake. The appropriate plant parts (roots, bark and leaves) are collected, prepared and poured to the water Eyo \& Ahmed [22].

The neurotic or suffocating effects eventually result in the fish floating belly up on the water surface where they are collected with scoop or clap nets. Most poisons affects the gills of fish and the flesh is safe for consumption Eyo \& Ahmed [22], although where synthetic chemicals are used, residues may accumulate in the flesh to toxic levels. Agbelege et al. [27] and Neiland et al. [28] reported the use of fish fence popularly known as "dumba" in Lake Chad Basin. "Dumba" is non-selective and non-discriminatory to species and sizes of fish. Dumba is made from rows of traps e.g. the Malian trap constructed with nylon net of fine mesh size of about sinch $(25 \mathrm{~mm})$ and arranged in rows of several $\mathrm{Km}$ (up to $10 \mathrm{~km}$ ) per rows across the water to form barriers to fish passages, "dumba" fishing as compared to other fishing methods rapidly and in- discriminatory deplete the stock as juveniles and undersize fishes constitute the catches of "dumba".

It is indeed an unorthodox and destructive fishing method. Nevertheless, the fishers in the Lake Chad have remained tenacious in the use of dumba which they regard as the most effective fishing method [28]. The effects of fishing pressure on the reduction of species biodiversity have been reported in Lake Chad Basin, Kainji Lake, the great African Lakes and Lake Malawi [29]. Ladu et al. [29] reported a situation of indiscriminate catches in Tiga, and Gabiri-Nguru, Kano and Yobe States, Nigeria respectively.

The author also revealed that the insufficient skills in handling fishing gears have led to destruction of some breeding site, hence depletion of the fish stock and catches in Hadeja Jama'are Komadugu, Yobe Basin (HJKB), Nigeria. DDT and 
Gamalin 20 are reported to be in use in many inland waters of Nigeria. These chemicals are extremely harmful to fish and its habitat. Ladu et al. [29] reported that the fish production trend of the Hadeja Jama' are Komadugu, Yobe Basin (HJKY), Nigeria had reduced qualitatively with about $40 \%$ for the past one decade. The same trend was reported for the fish sizes. The depletion was as a result of application of poison in temporary and permanent pools of water and erection of fish fence/barriers to trap migratory fishes.

It was observed that indiscriminate fishing in HJKY Basin due to non-enforcement of fishing management regulation have resulted in overfishing to the detriment of fisheries, especially the commercial and endemic species.

\section{Illegal, Unreported and Unregulated (IUU) Fishing Practices}

IUU fishing is often an organized criminal activity, professionally coordinated and truly global. Indiscriminate fishing is another problem. IUU undermines sustainability of managed fisheries, and adds substantial uncertainty to all aspects of evaluating the status of exploited stocks and ecosystems and effectiveness of management actions. Where IUU fishing is a major factor in unsustainable fishing of target species, it is likely to be a major threat to biodiversity conservation as well.

The key drivers for IUU fishing include High value/demand of fisheries products; Weak national, regional, and international fishery administration and management; Ineffective monitoring, control and surveillance (MCS); and Poverty, lack of alternative livelihoods, and inadequate social legislation.

The secondary factors include: Ineffective capacity management; Poor fisheries resource status; and Poor data collection and information exchange creating information gaps. Nwabeze \& Erie [3] reported that people are fond of using gears with undersize mesh to fish in Lake Jebba Basin especially the beach seine net. They mostly use it at night and when caught, they bribe their way. Beach seine net is an under-size net with a mesh size of less than $0.5 \mathrm{~mm}$ and a length of over $100 \mathrm{~m}$. It has the capacity to crop fish eggs, fry and juveniles of all species [30]. According to Alamu et al. [21], the reported declines of fisher's catches in Lake Kainji resulted from the use smaller meshed nets, which targeted all sizes of fish.

The use of fish fence traps by the Nupe fishers to trap fish during the retreat of flood waters in Lower Kaduna River and its flood plains have been reported. Artisanal fishers have been reported to use gillnets with undersize mesh sizes in Hadeju Nguru wet land. Illegal, unreported and unregulated (IUU) fishing is an economic problem that takes place in Lake Geriyo, Yola, Nigeria. It occurs in virtually all fisheries given that some fishermen don't report their catches, their level of fishery is hard to quantify. However catches of some species tends to be many times more than the permitted level due to IUU fishing.
A number of fishermen were found using small mesh nylon monofilament gill nets and Malian fish traps of less than 1 inch mesh sizes to catch fish in Lake Gerio, Yola. Many of the fishermen are aware that it is a bad method of fishing with but believed that small mesh size nets have higher catch rate than bigger mesh sizes. This has a negative impact on almost all the fish species in the lake as many juveniles were found in the catches. The information on the exploitation pattern at the lake Geriyo reveals the need for the conservation of the fisheries resources available for a long term sustainable exploitation because in recent years, there has been growing concern that the fisheries of north-eastern Nigeria have been increasingly overexploited [28] leading to a reduction in socio-economic benefits for local communities and the regional economy in general Adam [31] reported that fishing gears mainly used in Tatabu Flood Plain in Niger State, Nigeria are nets of which more than $80 \%$ of them are considered illegal $(<2.49 \mathrm{~mm}$ mesh size, stretched).

\section{Challenges of Artisanal Fisheries in Nigeria}

Omorinkoba et al. [32] highlighted the problems associated with fish handling in artisanal fisheries of Kainj Lake to include lack of credit facilities and revolving loan scheme for the fishers. Akankali and Jamabo [33] reported that several empirical evidences existing in literature shows that the fisheries yield from artisanal sources is on the decline in Nigeria. Druounye (2014) reported that the greatest challenge faced by artisanal fisheries in Taraba State of Nigeria is that it is operated by artisans who learnt the art informally from their parents and most of them cannot read nor write. They lack modern fishing equipment and can hardly maximize their catch in the face of the declining fisheries resources, climatic change and economic recession.

These have made the fishers to adopt the use of chemicals and some unsustainable fishing methods. The challenges confronting the development of artisanal fisheries in Nigeria are not unique to her alone but are common to other nations of the World especially in the developing countries. Some of these have been highlighted by Essen [34] and Moses [14] to include overfishing, obnoxious/illegal fishing methods, siltation, and oil pollution, among others. Some of these challenges are interwoven; one depending on the other and vary from one fishing community to another. The general challenges of artisanal fisheries in Nigeria include:

\section{Open access nature of the fisheries}

The open access property in which there is no restriction on entry into property because there is no property right is the main problem of fisheries in Nigeria. According to Etim [21] open access is a situation in which there is no restriction of entry into a common property irrespective of whether the property is owned by an individual, community or state. Artisanal fisheries in the state are open access property. Unrestricted entry into the inland fisheries of Nigeria has resulted in heavy fishing pressure 
on stocks. Lack of enforcement of extant regulations in artisanal fisheries is a common problem in developing countries due mainly to lack of manpower, equipment and political factors; like the case study in Ibeno Ifunanya [35].

\section{Over exploitation}

Although fishes are renewable resources, their stocks are not unlimited. They are amenable to overexploitation. In the past, people have erroneously thought that fisheries resources are inexhaustible. Etim [21] attributed over exploitation to invention and increased sophistication of fishing gear and craft such as steam trawlers, factory trawlers, and the technical developments such as the invention of the hydraulic winches, inboard refrigeration, and acoustic fish finders which came with the reality of man's ability to overexploit and deplete the water resources. Pro-Natura International (Nigeria), (2004) reported that a greater population of Eastern Obolo are fishermen/ fisherwomen and fish traders, who only indulge in crop/ animal/farming for subsistence. It is observed that the peoples' poverty has been enhanced by the serious depletion of fishes and dependence on fish as the only means of survival. Etim [21] highlighted the negative consequences of overfishing and collapsed fishery to include:

\section{a. Negative biological impact \\ b. Negative economic impact \\ c. Negative sociological impact}

\section{Obnoxious/illegal fishing practices}

Many authors reported that fishers including children and the aged in the riverine environments in Nigeria use Gammalin 20 , locally made hand grenade and the roots, leaves, fruits and flowers extracts of certain poisonous plants (partial poisoning) to kill fish [21]. This is a wrong method of fish exploitation since other useful macro- and micro-organisms essential for the stabilization of the ecosystems are exterminated. These plant extracts pollute the environment and reduce the fish stocks through uncontrollable mortality. Enyenihi [36] reported the wrong use of fishing gears in many inland waters of Nigeria such as nets of very small mesh sizes to catch fish as being a method of destabilizing the aquatic ecosystems. This leads to over-exploitation whereby the juveniles which would have been recruited into the fishery are caught along with the adults. The use of explosives such as locally made dynamites and hand grenades by fishers have been reported by many authors including Eyo \& Ahmed [22] Nwabezez \& Erie [3].

\section{Pollution}

The oil industry in the Niger Delta started commercial production in 1958 following the discovery of crude oil at Oloibiri by Shell British Petroleum (now Royal Dutch Shell), in 1956 [37]. The activities involved in petroleum exploration, exploitation and production produce wastes of varying chemical compositions, which are generated at each phase of the operation and it is the major source of pollution in this coastal state. The disposal of these wastes in the Niger Delta has polluted land and water, damaging fisheries and agriculture, undermining the human right to an adequate standard of living [38].

Effluents and wastes from oil industries which should be treated are dumped anywhere and they find their ways into the surface waters [38]. Pollution of the aquatic systems originates from different sources such as point and non-point sources $[36,39]$. The pollutants affect aquatic life in the sediments and the open water, thus leading to massive fish kill, including all the organisms that contribute to the food web of the commercially important fish species. Oil exploration and exploitation in our coastal waters and creeks cause the pollution of the aquatic environments which pose a serious threat to the survival and development of fish stocks. In the coastal waters especially estuaries, it destroys the nursery and feeding grounds, thereby impoverishing the artisanal fishers whose livelihoods are derived from such areas [35] Pollution kills fish, their food sources and fish larvae, and damages the ability of fish to reproduce, causing both immediate damage and long-term, cumulative harm to fish stocks. When oil and wastes are discharged into an enclosed body of water, fish are directly exposed to pollutants and can die $[35,40]$. In a moving body of water, such as a river, fish may be able to move away from the immediate vicinity of oil pollution but fish eggs and larvae cannot escape. This has caused a major decline in overall stocks, according to fisheries and environment pollution experts. Oil spills and other oil-related pollution have also seriously damaged the Niger Delta's mangroves, which are an important fish breeding area and are very hard to clean once polluted $[35,41]$ reported that Oil spillage that occurred in Ibeno local Government area of Akwa Ibom State, Nigeria was mostly as a result of pipeline vandalization.

Nsongurua et al. [42] reported the concentrations of four heavy metals: Lead, Cadmium, Arsenic and Selenium, were determined using Atomic Absorption Spectroscopy for analyzing water samples and four species of fish: Scomberomorus tritor, Pseudotolithus typus, Trichiurus lepturus and Shyrua zygaena, harvested from Ibeno, a Nigerian coastal area of the Atlantic Ocean. Comparisons with international standards revealed high levels of Lead and Cadmium in the Ibeno area of the Atlantic Ocean. In addition to natural geological processes, municipal wastes and agricultural runoffs, the high level of heavy metal is attributable to the oil exploration activities of the oil industry in the area [43].

\section{Climatic change}

Fish production like other productions is influenced by climatic factors [44]. Ekpo \& Nzegule [38] reported that changes in the key water variables (temperature, salinity, wind speed direction, ocean currents, and strength of upwelling) affect the abundance and distribution of fish population and fisheries activities. The impact of climate change on aquatic ecosystem include increased in mean annual temperature, latitudinal and 
depth shift in range, lower dissolved oxygen concentration, coral bleaching, threat to mangrove swamps, phenology of marine organisms and ocean acidification [44-46].

Global warming accounts largely for the near disappearance of Lake Chad in northeast Nigeria from the 1970s to 2001, the reduced volume of water (due to high evaporation rate caused by excessive high temperature) will automatically bring about reduced fish output, hence, the fishers may experience hardship. The anthropogenic stressors such as fishing, pollution and habitant alteration, accentuate climate impacts on aquatic ecosystems and the exploited fish populations, by reducing their resilience and increasing their sensitivity to climate change [46].

\section{Post-harvest losses}

Generally, artisanal fisheries is characterized by lack of or hired processing and storage facilities. This condition leads to high rate of post-harvest fish losses. Bolorunduro [47] had observed that despite the subsistence nature of capture fisheries in Nigeria, as much as $50 \%$ of post-harvest loses has been recorded which is partly due to poor post- harvest handling facilities. Fish is a highly perishable commodity and as such it is usually frozen or canned in order to [32] prevent post harvest losses Nkeme et al. [48]. It was reported that overfishing in Lake Chad Basin is generally of a lesser danger than habitat changes because it can be correlated by standard fishery methods once it is detected and fish populations are known to be resilient in compensating overfishing by adjusting their reproductive behavior Ahmed [22].

\section{Distribution and marketing of fish products}

After harvesting, fish products need to reach the final processors and consumers through the networks of fish distributors and marketers while they are still in good conditions. This is where the middlemen services are very important. Lack of transportation may mean that fish products will not get to the areas that need them [49]. Therefore, fast movements by distributors and marketers will help to reduce spoilage. [41] inferred that both fresh and dried fish marketers in Akwa Ibom State (Nigeria) fishing ports are united in their perception of extension needs requirement for improved fish marketing activities.

\section{Decline in biodiversity}

Habitat destruction resulting to loss of biodiversity is a common problem worldwide, particularly in developing countries where a high percentage of the populations are dependent on the exploitation of the free gift of nature [28]. In any over-exploited fish population, the fishery always disappears before the species [14]. Protopterus annectens (Polypteridae) and Xenomystus nigri (Notopteridae) were reported in Ikpa River of Akwa Ibom State, Nigeria but in recent studies by Ekpo [50], they were not found. Species extinction is generally associated with habitat modification, perturbation and destruction. Ekpo [50] reported that some common anthropogenic perturbations of aquatic systems include alterations in eco-hydrological regime, habitat area, habitat quality, water quality, substrate quality and biotic interactions and energy source.

Additionally, the authors showed that the introduction of exotic biota by man could perturb the ecological integrity of aquatic ecosystems, as the alien species may often replace the indigenous species. Amiye et al. reported that Papyrocranus afer, Heterotis niloticus, Gymnarchus niloticus, Citharinus citharus, Labeo senegalensis, Clarias anguillaris, Hepsetus odoe, Ctenopoma kingsleyae, Chromidotilapia guntheir and Hemichromis elongatus are among the endangered species in Lake Oguta. According to Njoku \& Ejiogu [23], in 1989, 98 fish species were caught from Lake Oguta which belonged to 28 piscean families which is against just 41 species drawn from 18 families recorded decades after. Ladu et al. [29] reported that 15 fish species are being threatened in the Hadeja Jama' are Komadugu Yobe Basin, Nigeria.

The highest threat frequency was recorded for Gymnarchus followed by Citharinus while the lowest threat frequency was recorded for 8 different species (Alestes, Lates, Hydrocynus, Cynothrissa mentho, Erpetoichyths and Auchenoglanis) some of the species reported as threatened in some areas have been as a result of overfishing of such species due to their high demand. Some of the species declared threatened might have been shielded or affected by the evasion of aquatic macrophtes [29]. The authors reported three new species in the Basin. These include Arius, Heterotis and Momyrops. These species must have escaped through river tributaries into the Basin because they have been earlier reported in River Niger.

\section{Failures on the parts of the nigerian government and the oil companies}

According to Amnesty International (2009), among the critical failures of the government are:

(1) Multiple failures to effectively regulate and control the oil industry.

(2) Failure to monitor the impacts or provide people with adequate information.

(3) Failure to deal with people at risk devolving critical areas of human rights responsibility to the oil companies.

(4) Failure to ensure access to remedy entrenched in law, a system that allows land to be taken from communities for oil operations.

(5) Lack of adequate protections as required by human rights law.

Poor management of the water bodies by the relevant government authorities results in low productivity and consequently low catches by fishers. This has led to the use of undesirable fishing gears by some fishers and application of very destructive fishing methods by others [41,42]. Some of these 
problems have been tackled by the government at different times but lack of continuity frustrates development efforts and there is therefore a need for a co-ordinated effort at all levels of development and management to ensure continuity.

\section{Artisanal Fisher's Adherance to Fisheries Regulations}

Many authors have reported low compliance to fishing regulations by fishers especially in developing Nations including Nigeria. Nwabeze \& Erie [3] reported that over half (57\%) of fishers in Lake Jebba Basin never used any sustainable fishing practice, while only $39.1 \%$ used only one form of sustainable fishing practice. $60 \%$ and $50 \%$ of them reported using gill nets and hook and lines respectively. They further reported that nonuse of poison, explosives, fish fence were the most practiced fishing regulations by the fishers. Others are gear control, declaration of fish catch, fishing effort control, closed seasons and closed areas [3].

The researchers attributed reasons for the low conformity of regulations to poor implementation of formal sanctions by law enforcement agents and centralization of the then Fisheries Decree of 1992. On the fisher's attitudes towards formal fishing regulations, Nwabeze \& Erie [3] reported that the fishers in Lake Jebba Basin are disposed to formal fishing regulations. The leading attitudes are ban on fish fence and gear control. Less than $30 \%$ of them supported closed seasons and closed areas as fisheries regulations.

To achieve sustainable and socially beneficial exploitation of fisheries resources led to the promulgation of the Fisheries Act, 2014 [50]. Despites this effort, little have been achieved on the pathway to sustainability on Fisheries resources. Anaikele \& Olutayo reported that low compliance to fishing regulations in Lagos State, Nigeria. According to the authors, only about $34 \%$ of the fishers conform to the provisions of fishing regulations while $66 \%$ are not conforming to the regulations guiding fishing in the area. They further reported that the fishers did not perceive the regulations as capable of addressing the sustainable supply and exploitation of fisheries resources.

They did not see the need to conform to the provisions of the regulations, perhaps because they have a non-empirical explanation for the depletion of stocks and how to achieve abundant supply of fisheries resources. They revealed that the penalties for unsustainable fishing practices are too cheap to have any serious impact on defaulters which is why fishers violate the fishing regulations. They reported poor monitoring and enforcement of the regulations by those responsible.

\section{Benefits of Sustainable Fisheries Practices}

Fishes are renewable natural resources which should be exploited rationally on sustainable basis. To derive maximum benefits from them, it is necessary to evolve effective management strategies that will make available the resources now and in the future, at the time we need them, in a very good condition at affordable prices and should improve the economic well-being of fishers, and should also be environmentally friendly. Sustainable fisheries and the ecosystems in which they function provide significant benefits which are discussed below. A transition to any sustainable management of fish stocks should ensure that these benefits are available today and to the future generations $[51,52]$.

\section{Economic benefits}

Currently, fisheries contribute approximately US $\$ 274$ billion to global GDP [53]. This number increases by further US\$160billion per year when upstream activities such as boat making are included [53]. Fisheries contribute to economies through tax generation and fish products are now being traded commodity generating valuable foreign exchange particularly for developing countries (with a total export earnings of USD 50 million while the import value was USD 375.03 million in Nigeria in 2001 as reported by FDF [5]. FAO estimates that $37 \%$ of fish are now traded internationally, making it one of the most traded protein commodities, generating US $\$ 102$ billion in export value [53]. Developing countries had a net export for fish products of US $\$ 27$ billion which is significantly higher than other traded commodities like coffee and Rice [52].

\section{Livelihood benefits}

A sustainable fishery is one that provides safe, secure and long-term employment [53]. Fisheries globally, employ between 120 and 200 million people both directly as fishers and indirectly in activities such as processing, marketing, distribution of fish products etc. $97 \%$ of those employed in fishing are in developed countries [53], and the vast majority of them are artisanal fishers. Fisheries have an important role to play in both poverty prevention and reduction. Sustainable management of fisheries not only provides steady and long-term employment opportunities, but also a better standard employment [53]. There are many examples of this around the World. Sustainable fisheries are also more likely to attract future generations to fishing and at the same time encourage innovations [53].

\section{Food and nutritional security}

The contribution of fish and fish products to global nutrition is of great importance. One study recently concluded that if overfishing had not been so dramatic, approximately 20 million people could have avoided under-nourishment in 2002 [53]. Fish catches have been contributing directly and indirectly to individual or nation food security; directly through the supply of the food commodity itself that is subsistence level and indirectly when income obtained by those involved in the fishing industry [54] is used to purchase food for families [53].

The contribution of fish already vital to the World's food security and may become ever more important given the challenges that lie ahead for terrestrial food production [53]. A recent analysis has suggested that shifting $20 \%$ of the world's 2010 calorie consumption from meat to fish would save 6080 million hectares of cropland [53]. According to most recent 
FAO [55] figures, fish consumption has reached an all time approximately $17 \mathrm{~kg}$ per year, supplying approximately 1 billion people with their main protein source [53].

\section{Ecosystem resilience and services}

Sustainable fisheries will help increase the resilience of the ecosystems, which in turn ensures the availability of other benefits provided by the ecosystems. Aesthetic enjoyment of the natural world can also be considered an ecosystem service. Charismatic organisms like whales or attractive natural landscapes such as coral reefs, for example, provide aesthetic value. Sustainability helps conserve species and important habitats in the ecosystem [53].

\section{Conclusion and Recommendation}

It is evident that inland fisheries have been contributing significantly to human existence in the areas of food and nutritional security, job/employment creation, national economy development, conservation, raw materials for industries etc. These benefits are at risk because their sustainability is threatened by many factors and human activities including unsustainable fisheries practices by artisanal fishers [56]. The need to adopt measures that will ensure continuous availability of these fisheries resources and its benefits cannot be overemphasized. Since artisanal fisheries provides crucial role in the socio-economic and political well-being of many Nigerians, there is need to ensure complete protection, development, management and sustenance of both its aquatic environment and its vast inland fisheries resources to ensure the sustainability of the resources and avoid possible stock depletion and collapse. Managing fisheries resources sustainably eventually means more profits, good nutrition and more jobs for many people.

Based on the conclusions of this work, the following recommendations are made:

i. Enlightenment campaign on the use of sustainable fisheries practices for continuous sustenance of the inland fishing grounds. This can be achieved through seminars and workshops, symposia, radio and TV programs, brochures and posters, as well as festivals.

ii. There is need to strengthen artisanal fishers as key stakeholders in fisheries policy formulation, implementation and evaluation. This will entrust commitment and ownership on the part of the fishers towards the realization of formal fisheries policy and sustainability objectives.

iii. There is need to recognize the traditional/informal institutions by Government. Their effort will complement that of the formal law enforcement agents whose manpower are grossly inadequate coupled with the challenges in reaching the scattered inland fishing grounds [3].

The need to diversify the artisanal fisher's source of income cannot be overemphasized. This can be done through the promotion of aquaculture and other forms of farming. This will reduce the pressure on the fisheries resources. Holistic approach to fisheries management requires that solutions to low income be dealt with outside the fishery. Access to capital and providing an enabling environment will encourage fishers to engage in non-fishing activities and thereby allow the fishery to recover. Industrial activities (especially oil exploration) should be carried out in an environmentally friendly manner and where damage occurs, it should be remediated as soon as possible and adequate compensation paid accordingly.

The inland fisheries Act [50] (as enshrined in the Fisheries Act, 2014 of the Federal Republic of Nigeria) along with other relevant fisheries edicts and regulations should be strictly enforced. There is need for proper control, monitoring and surveillance of inland fisheries waters of Nigeria by all relevant enforcement agents to ensure total compliance with the fisheries laws, edicts and regulations. There is need to provide room for co-management of the inland fisheries resources to any relevant and interested organizations, groups and institutions who are willing and capable of com-anaging the inland fisheries resources of Nigeria. Regular restocking and habitat manipulation programmers of depleted and over fished inland waters in order to resuscitate the fisheries resources [57].

The code of conduct for responsible fisheries adopted at the FAO Conference held 0n 31st October, 1995 should be integrated into any management plan and its importance made known to the fishers. The code sets out principles to conserve, manage, and sustainably use living aquatic resources. It works to protect the world inland, marine and coastal waters with due respect for biodiversity and the ecosystem. All penalties for violations should be prohibitive enough to render gain derived not worth effort.

\section{References}

1. Neiland AE, Bene C, Jolley T, Ladu BMB, Ovie S, et al. (2002) Fisheries of the Lake Chad Basin; an update on current knowledge and development. In: Neiland AE, Bene C (Eds.), Sustainable Development of African Commercial Fisheries: a regional study of policy options and policy formation Mechanism in the Lake Chad Basin. Final Report, European Commission INCO Project No. ERD1C118CT980331.

2. Bene C, Heck S (2005) Fish and Food Security in Africa. NACA, World fish Center Quarterly 28(3-4): 8-13.

3. Nwabeze GO, Erie AP (2013) Artisanal Fishers use of sustainable Fisheries Management Practices in the Lake Jebba Basin, Nigeria. Journal of Agricultural Extension 17(1): 123-134.

4. Food and Agriculture Organization (2010) Fact Sheet: the international fish trade and World Fisheries. FAO, Rome, Italy.

5. Federal Department of Fisheries (2013) Fisheries Statistics of Nigeria. Federal Ministry of Agriculture and Rural Development, Abuja, Nigeria.

6. Food and Agriculture Organization (2010) Report on the African Regional consultative meeting on security sustainable Small-scale Fisheries and social development. Fisheries and Aquaculture report No. 963, Maputo, Mozambique.

7. Mutume G (2002) Africa seeks to Safeguard its Fisheries. Africa Recovery 16(1): 12 . 
8. Akeem OS (2011) Sustainable Fisheries Management through Efficient Fisheries resource Data. Statistics. Journal of Fisheries and Aquatic Sciences 6(3): 202-211.

9. Ajayi TO (1982) The Maximum Sustainable Yields of the inshore Fish and Shrimp resources of Nigerian Continental Shelf. Journal of Fish Biology 20(5): 571-577.

10. Ohoen SB, Agom DE, Okon UH (2009) Economics of Cat fish Farming in Rivers State. Proceedings of the $23^{\text {rd }}$ Annual Conference of Farm Management Society of Nigeria, $14^{\text {th }}-17^{\text {th }}$ Dec, Sokoto, Nigeria, pp. 570-572.

11. Food and Agriculture Organization (2007) Fish Country Profile, FAO. The Federal Republic of Nigeria. FID/CP/NIF, p. 24.

12. World Fish Center (2008) Fish and Food Security in Africa. World Fish Center Planning, Malaysia.

13. Moses BS (1990) Introduction to Tropical Fisheries. IUP and UNESCO/ ICUS, Paris. Ibadan University Press, Nigeria, p. 117.

14. World Bank (2009) The Sunken Billions. The economic Justification for Fisheries Reform: examples of Economic studies on specific Fisheries, Washington, USA.

15. Food and Agriculture Organization (2013) Nations for a World without Hunger. Department of Fisheries and Aquaculture, FAO, Rome, Italy.

16. Food and Agriculture Organization (2009) Fisheries and Aquaculture Report No. 932 on Exert meeting on the Impacts of Destructive Fishing Practices, Un-sustainable fishing and Illegal, unregulated and unreported fishing (IUU) Aquatic Biodiversity and Habitat. FAO, Rome, Italy.

17. Solarin BB, Kusemiju K (2003) Fish shelters as Fish Enhancement Techniques in Lagos Lagoon, Nigeria. Nigeria Journal of Fisheries 1(1): 57-61.

18. Enaikele MD, Olutayo AD (2010) Explorative Analysis of the Effects of Inland Fisheries Decree on Sustainable exploitation of Inland Fisheries in Lagos State, Nigeria. Journal of Agricultural Extension and Rural Development 8(1): 154-160.

19. Etim L (2010) The Tragedy of the Commons: Alleviating the Tragedy of the Commons in Nigerian Waters. The $27^{\text {th }}$ Inaugural Lecture of the University of Uyo held on $27^{\text {th }}$ May, 2010. University of Uyo Press, Nigeria, p. 60.

20. Alamu SO, Okonoda JK, Omorinkoba WS (2001) Cooperative Management of Artisanal Fisheries implementation of Democratic Principles in Fisheries Management Around Lake Chad Basin. FISON Proceedings.

21. Eyo AA, Ahmed YB (2005) Management of Inland Capture Fisheries and Challenges to Fish Production in Nigeria. Federal College of Freshwater Fisheries Technology, New-Bussa, Nigeria, pp. 624-634.

22. Njoku DC, Ejiogu CO (2005) Fisheries and Wildlife of Nigeria. Okson Publishers, Owerri, Nigeria.

23. Njoku DC, Orji RC, Peter KJ (2010) Morpho- meristic Analysis and the Identity of The Moon Fish, Citharinus distichdoides (Pieces: Citharinidae) of Lake Oguta, Nigeria; Towards a Restocking Programme for a depleted Inland Fishery. Journal of Aquatic Sciences 25(1): 45-51.

24. Ita, Balogun (1983) Impact of the use of Explosives and Poison substances in fishing in Oguta Lake, Nigeria. Wyners Publishers, Owerri, Nigeria.

25. Oruounye ED (2014) The Challenges of Fisheries Resources Management practices in Mayo Renewo Community of Ardo Kola Local Government, Taraba State, Nigeria. Global Journal of Science Frontier Research 14(3): 28-36

26. Agbelege 00, Omoyeni BA, Aisami U (2002) Implications of Aquatic Macrophyes Boom in and its implications on the Lake Chad Fishery. Paper presented at FCFFT, Baga, Nigeria.
27. Neiland AE, Madakan SP, Bene C (1990) Implications of Aquatic Macrophyes Boom in and its implications on the Lake Chad Fishery Proceedings of the Seminar on sustainable Livelihoods and the management of fisheries in the Sahel, FAO/CIFA. Italy.

28. Ladu BMM, Sogbesan AO, Tafida AA (2013) Fisheries and Fishing Enterprises in the Hadeja Jama are Komadugu Yobe Basin, Nigeria. Technical Report, Hadeja Jama are Yobe Basin-Trust Fund, Nigeria.

29. Nwabeze GO, Ifejika PI, Ayanda JO, Arie AP, Onemolease EA (2011) Perceived effects of Corrupt Practices in Fisheries Livelihood of Fisherfolks in Borgu Local Governement, Niger State, Nigeria. MiddleEast Journal of Scientific Research 8(3): 555-561.

30.Adam WM (1985) The Downstream Impacts of Dam Construction; a case Study from Nigeria. Transactions of the Institute of British Geographers. 10: 292-302.

31. Omorinkoba WS, Ogunfowara 00, Aga ND, Mshelia MB (2011) Artisanal Fisheries Activities in Lake Kainji. In: Raji AA, Okaeme N, Ibeun MO (Eds.), Forty Years on Lake Kainji Fisheries Research pp. 43-53.

32. Akankali JA, Jamabo NA (2011) A Review of some factors militating against Sustainable Development of Artisanal Fisheries in Niger- Delta, Nigeria. Asian Journal of Agriculture Sciences 3(5): 369-377.

33. Essen AA (1990) Review of the Fisheries resources of Akwa-Ibom State and the need for Effective Conservation 1: 116-129.

34. Ifunanya AS (2010) The Impacts of Oil Spillage on Agriculture Production: a case study of Ibeno Local Governement, Akwa Ibom State, Nigeria, p. 17.

35. Enyenihi UK (1990) Biological Conservation for Environmental Stability and Food Production. Trans. Nigeria Society of Biological Conservation 1: 4-10.

36. lution and Poverty in Niger Delta. Amnesty International Publications, London, England.

37. Ekpo FE, Nbebule EC (2012) Climatic Change Impact and Adaptation opportunities on Agricultural Production in Communities around Itu Bridge-Head in Itu Local Governement. Nigeria. International Journal of Environmental Sciences 2(4): 2191-2202.

38. Onuoha GC (2009) Fundamental Principles of Fisheries Science (New edition). Digital Press, Umuahia, p. 164.

39. King RP, Jonathan GE (2003) Aquatic environmental perturbations and monitoring. African Experience, USA, p. 166.

40. Imaobong EE, Mandu AE (2013) Development, Prospects and Challenges of Artisanal Fisheries in Akwa Ibom State, Nigeria. International Journal of Environmental Science, Management and Engineering Research 2(3): 69-86.

41. Azionu BC, Ovie, SI, Adigun B, Atribom BY (2005) Aquaculture and Inland Fisheries Project Newsletter (2014). Prospects and Problems of Nigerian Inland Capture Fisheries: the Dimension of Sustainability. Fisheries Society of Nigeria, Book of Abstract. pp. 49.

42. Nsogurua AE, Akintola A, Ishaya G, Olonipekun I, Ibraheem AS, et al. (2011) The level of some Heavy Metals in Fish Harvested from Ibeno (A coastal area of the Atlantic Ocean). J Basic Appl Sci Res 1(12): 29602964.

43. Akpan AW (2003) Total Hydrocarbon Concentration in the Coastal soil, Sediments and Water in Qua Iboe estuary (Nigeria) in relation to Bioturbation and precipitation 16(2): 39-47.

44. Ipinmoroti O (2012) Salvaging Fisheries Systems in the Face of Climate Change. In: Etim L, Oribkabar B (Eds.), Current Issues in Sustainable Tropical Agriculture. Faculty of Agriculture, University of Uyo, Nigeria 18: 167-175.

45. Daw T, Arger WN, Brown K, Badjeck MC (2009) Climatic Change and Capture Fisheries: potential impacts, adaptation and mitigation. FAO Fisheries and Aquaculture Technical Paper No. 530, Rome, Italy, pp. 107-150. 
46. Enim UI (2012) What Concerns Nigerian Fishers with Climate? Current Issues in Sustainable Tropical Agriculture. Faculty of Agriculture, University of Uyo, Nigeria, 1: 1-13.

47. Bolorunduro P (1996) Livestock and Fish Production Technology for Women in Agriculture. La proceedings of National Trading Workshop held at NAERI. pp. 65-68.

48. Nkeme KK, Ndaeye NN, Akpaeti AJ (2013) Chorkor Smoker Kiln Technology Adoption in Akwa Ibom State, Nigeria: constraints, and Prospects. American Journal of Research communication 1(3): 89-96.

49. Ekpo IE (2013) Effects of physico-chemical parameters on zooplankton species and density of a tropical rainforest river in Niger Delta, Nigeria using Canonical Cluster Analysis. International Journal of Engineering and Sciences (IJES) 2(4): 13-21.

50. Federal Department of Fisheries (2014) Fisheries Statistics of Nigeria. Federal Ministry of Agriculture and Rural Development, Abuja, Nigeria.

51. Food and Agriculture Organization (2010) Report on the African Regional consultative meeting on security sustainable Small-scale Fisheries and social development. Fisheries and Aquaculture report No. 963, Maputo, Mozambique.
52.ISU (2012) Towards Sustainable Fisheries: the opportunity for Transition. International Sustainability Unit.

53. Faturoti EO (2000) Beneath the Ripples and Sustainable Fish Production. Inaugural Lecture, University of Ibadan, Nigeria, p. 54.

54. Food and Agriculture Organization (2006) State of world Aquaculture. FAO Fisheries Technical Paper No. 500. FAO, Rome, Italy.

55. Food and Agriculture Organization (2010) State of World Fisheries and Aquaculture, 2010. FAO Aquaculture Global and Regional Reviews, Rome, Italy.

56. FDF (2009) Fisheries Statistics of Nigeria. Federal Department of Fisheries, Abuja, Nigeria.

57. Pro-Natura International (2004) Status Report on Community Natural Resources in Eastern Obolo Local Government, Akwa Ibom State, Nigeria. A participatory Rural Appraisal Report by Natural Resources Advocacy Team.

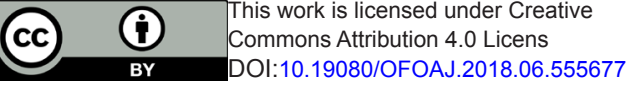

